\title{
The Bankruptcy-Law Safe Harbor for Derivatives: A Path-Dependence Analysis $^{1}$
}

\author{
Steven L. Schwarcz* \\ Ori Sharon**
}

\begin{abstract}
U.S. bankruptcy law grants special rights and immunities to creditors in derivatives transactions, including virtually unlimited enforcement rights. This Article argues that these rights and immunities result from a form of path dependence, a sequence of industry-lobbied legislative steps, each incremental and in turn serving as apparent justification for the next step, without a rigorous and systematic vetting of the consequences. Because the resulting "safe harbor" has not been fully vetted, its significance and utility should not be taken for granted; thus, regulators, legislators, and other policymakers-whether in the United States or abroad-should not automatically assume, based on its existence, that the safe harbor necessarily reflects the most appropriate treatment of derivatives transactions under bankruptcy and insolvency law or the treatment most likely to minimize systemic risk.
\end{abstract}

1. This Article was originally prepared for presentation at the November 7-8, 2013 Federal Reserve Bank of Chicago-International Monetary Fund conference on "Shadow Banking Within and Across National Borders."

* Stanley A. Star Professor of Law \& Business, Duke University School of Law, and Founding Director, Duke Global Capital Markets Center; schwarcz@law.duke.edu. The authors thank participants in the conference referenced above, see supra note 1, participants in a faculty workshop at Duke University School of Law, and Stephen D. Adams, Stephen Lubben, and Edward Tang for their valuable comments.

** S.J.D. candidate, Duke University School of Law. 


\section{Table of Contents}

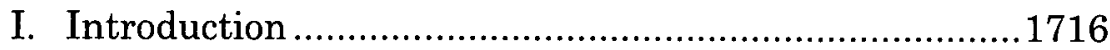

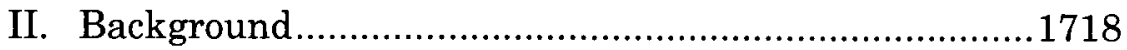

III. The Concept of Path Dependence................................1721

A. Defining Path Dependence......................................1721

B. Legal Path Dependence.........................................1722

IV. Evolution of the Bankruptcy-Law Safe Harbor

for Derivatives ............................................................1724

A. The 1978 Bankruptcy Code....................................1724

B. The 1982 Amendment ..........................................1727

C. The 1984 Amendment .............................................1728

D. The 1990 Amendment ..........................................1729

E. The Bankruptcy Abuse Prevention and

Consumer Protection Act of 2005............................1731

F. The Financial Netting Improvements Act

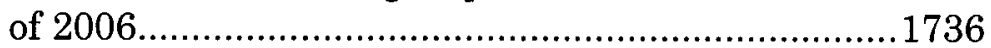

V. Is the Derivatives Safe Harbor Path Dependent? ........1737

VI. Reassessing the Derivatives Safe Harbor ....................1742

A. Does Market Concentration Justify the Safe Harbor?

B. Is the Safe Harbor Focused on the Right Parties?

C. Possible Unintended Consequences. 1747

VII. Conclusions 1753

\section{Introduction}

Bankruptcy law in the United States, which serves as an important precedent for the treatment of derivatives under insolvency law worldwide, ${ }^{2}$ provides unique protections to

2. The International Swaps and Derivatives Association (ISDA), the international financial trade association which represents financial institutions from forty-seven countries on six continents in the privately negotiated, or overthe-counter (OTC), derivatives industry, often looks to U.S. derivatives legislation and bankruptcy exemptions as the basis for proposed foreign derivatives legislation and exemptions. See, e.g., David Mengle, The Importance 
creditors in derivatives transactions. Unlike other creditors of a debtor, ${ }^{3}$ derivatives counterparties have special rights and immunities in the bankruptcy process, including virtually unlimited enforcement rights against the debtor (hereinafter, the "safe harbor"). This Article shows that these rights and immunities accreted over time, primarily due to industry lobbying and without a systematic and rigorous vetting of the consequences.

This type of legislative accretion process is not uncommon. It is a form of path dependence-a process in which the outcome is shaped by its historical path. Because the resulting legislationin our case, the safe harbor-is not fully vetted, its significance and utility should not be taken for granted.

This Article first provides background on U.S. bankruptcy law and derivatives transactions. ${ }^{4}$ Thereafter, it explains the concept of path dependence, including legal path dependence. ${ }^{5}$ The Article then reviews the evolution of the safe harbor for derivatives ${ }^{6}$ and shows why that evolution has been largely path

of Close-Out Netting, ISDA RES. Notes, no. 1, 2010, at 4-5 (using the U.S. bankruptcy law safe-harbor exemption for close-out netting to "illustrate[ the types of safe harbor provisions that are necessary to make netting enforceable"); William J. Bergman, Robert R. Bliss, Christian A. Johnson \& George G. Kaufman, Netting, Financial Contracts, and Banks: The Economic Implications 12 (Fed. Res. Bank of Chi., Working Paper No. 2004-02) (observing that the "widespread adoption of carve-outs, providing pro-creditor protection for payment systems and derivative instruments, particularly in the form of collateral arrangements and netting agreements, represents one of the few successes in international legal harmonization. This process has been shepherded by [ISDAl"). Cf. Letter from Katherine Darras, General Counsel, Americas, ISDA, to Susan E. Voss, President, Nat'l Ass'n of Ins. Comm'rs, and James R. Mumford, Chair, Receivership and Insolvency (E) Task Force, Nat'l Ass'n of Ins. Comm'rs (June 3, 2011) (on file with the Washington and Lee Law Review) (observing that "over thirty-seven countries have enacted legislation that expressly recognizes close-out netting for derivatives transactions" and suggesting some correlation between that foreign legislation and U.S. bankruptcy law recognition of close-out netting).

3. A debtor is any person or entity that is the subject of a bankruptcy case. 11 U.S.C. $\$ 109$ (2012).

4. See infra Part II (setting forth the relevant backgrounds of each).

5. See infra Part III (introducing the varied and interdisciplinary forms of path dependence).

6. See infra Part IV (observing and explicating the changes over time of safe harbor legislation). 
dependent. ${ }^{7}$ Finally, the Article reviews the scholarship that substantively engages the merits of the safe harbor. ${ }^{8}$ That scholarship suggests there is a serious question whether the benefits of the safe harbor exceed its costs, and that the safe harbor may even have unintended harmful consequences.

\section{Background}

Broadly speaking, bankruptcy law, which in the United States is governed by the federal Bankruptcy Code, ${ }^{9}$ favors derivatives (including repurchase agreements) counterparties in three main ways. ${ }^{10}$ Most prominently, it allows derivatives counterparties to exercise their contractual enforcement remedies against a debtor or its property-including closing out, netting, and setting off their derivatives positions and liquidating collateral in their possession-notwithstanding the automatic stay of enforcement actions. ${ }^{11}$ Secondly, bankruptcy law exempts derivatives counterparties from the so-called "[trustee-]avoiding powers," such as preference rules and constructively fraudulent transfers, regarding any payments and collateral received prior to the bankruptcy. ${ }^{12}$ For example, a derivatives counterparty that receives a preferentially large repayment from an insolvent debtor shortly before the debtor's bankruptcy will not have to return it. ${ }^{13}$ Lastly, bankruptcy law allows derivatives

7. See infra Part V (arguing that the changes as noted are path dependent).

8. See infra Part VI (providing a comprehensive overview of the salient scholarship on the merits of the safe harbor).

9. 11 U.S.C. $\S \S 101-1532$ (2012).

10. See Edward R. Morrison \& Joerg Riegel, Financial Contracts and the New Bankruptcy Code: Insulating Markets from Bankrupt Debtors and Bankruptcy Judges, 13 AM. BANKR. INST. L. REv. 641, 645-46 (2005) ("The Code calls off the automatic stay, prohibition on ipso facto clauses, and its preference and constructive fraudulent conveyance rules." (citations omitted)); Shmuel Vasser, Derivatives in Bankruptcy, 60 Bus. LAw. 1507, 1509 (2005) (identifying the same three changes).

11. See 11 U.S.C. $\S \S 362(b)(6)$, (7), (17), (27), 553(b)(1), 555-56, 559-62 (2012) (establishing particular derivative-counterparty-friendly tenets of the Bankruptcy Code).

12. Id. $\S 546(\mathrm{~g}),(\mathrm{j})$.

13. See id. $\S 546(\mathrm{~g})$ ("[T] he trustee may not avoid a transfer, made by or to 
counterparties to enforce bankruptcy-termination ipso facto clauses $^{14}$ and to net all existing derivatives contracts with the debtor. ${ }^{15}$ This effectively exempts derivatives contracts from a debtor's ability to terminate unfavorable contracts. ${ }^{16}$

To fully grasp the significance of these exemptions, we must first discuss the rationales underlying bankruptcy law's debtor protections. The most notable of the Bankruptcy Code's debtor protections is the automatic stay, which prevents the debtor's creditors from executing their rights against the debtor or its property. ${ }^{17}$ The automatic stay thereby not only protects the debtor but also prevents creditors from taking enforcement actions "in pursuit of their narrow self-interests." 18 The stay's legislative purpose is to allow companies attempting to restructure their debt under Chapter 11 "a breathing spell and time to work constructively with [their] creditors."19

(or for the benefit of) a swap participant or financial participant, under or in connection with any swap agreement and that is made before commencement of the case ....").

14. See id. $\S \S 559-61$ (establishing the limited ability of counterparties to enforce ipso facto clauses).

15. Upon default of a debtor, derivatives counterparties are allowed to terminate all existing derivatives trading with the debtor and reduce the contracts to a single "net" claim. This ability effectively eliminates a debtor's ability to terminate unfavorable contracts. See infra Part II.D-F (providing more fully for the legal theories and authorities that allow for netting).

16. Debtors otherwise have this ability. See 11 U.S.C. $\$ 365(a)$ ("Except as provided ... the trustee, subject to the court's approval, may assume or reject any executory contract or unexpired lease of the debtor.").

17. H.R. REP. No. 95-595, at 340 (1977), reprinted in 1978 U.S.C.C.A.N. 5963, 6296-97

The automatic stay is one of the fundamental debtor protections provided by the bankruptcy laws. It gives the debtor a breathing spell from his creditors, stopping all collection efforts, all harassment, and all foreclosure actions. It permits the debtor to attempt a repayment or reorganization plan, or simply to be relieved of the financial pressures that drove him into bankruptcy.

See also S. REP. No. 95-989, at 54-55 (1978), reprinted in 1978 U.S.C.C.A.N. 5787, 5840-41.

18. Douglas G. Baird, Bankruptcy's Uncontested Axioms, 108 YALE L.J. 573, 583 (1998) (citation omitted).

19. Adam R. Waldman, OTC Derivatives \& Systemic Risk: Innovative Finance or the Dance into the Abyss?, 43 AM. U. L. REv. 1023, 1063 (1994) (alteration in original) (citing H.R. REP. No. 95-595, at 174 (1977), reprinted in 1978 U.S.C.C.A.N. 5963, 6135, 1978 WL 9628). 
The automatic stay is a core element of any attempt to reorganize under the Code. By shielding the debtor's assets and preventing a race that rewards the first creditor to the courthouse, it avoids dismemberment of a firm with goingconcern value and facilitates a collective proceeding in which the parties (debtor and creditors) can negotiate the terms under which the firm will continue as a going concern. ${ }^{20}$

Preference rules are aimed at enabling debtors in bankruptcy proceedings to revoke transfers that were made in a manner that prefers certain creditors over others. The governing principle underlying preference rules is equality of distribution. Preference rules apply to transactions executed within the ninety days prior to bankruptcy filing. ${ }^{21}$

Section 365 of the Bankruptcy Code provides debtors with the ability to "assume or reject" executory contracts. ${ }^{22}$ A debtor may "cherry pick" which executory contracts to assume and which to terminate. ${ }^{23}$ The governing principle underlying this exceptional legal power is one of debtor rehabilitation and is aimed at assisting the debtor to successfully reorganize. ${ }^{24}$

20. Franklin R. Edwards \& Edward R. Morrison, Derivatives and the Bankruptcy Code: Why the Special Treatment?, 22 YALE J. REG. 91, 95 (2005); see also Bryan G. Faubus, Narrowing the Bankruptcy Safe Harbor for Derivatives to Combat Systemic Risk, 59 DuKe L.J. 801, 828-29 (2010)

In other words, the automatic stay restrains creditors not only to preserve the resources of the debtor firm but also to ensure that resources are distributed to creditors in an efficient and equitable fashion. In this way, bankruptcy law avoids the unnecessary costs that a grab race would otherwise impose on both the debtor and slower creditors.

21. 11 U.S.C. $\$ 547$; see also Travelers Ins. Co. v. Cambridge Meridian Grp., Inc. (In re Erin Food Servs., Inc.), 980 F.2d 792, 801 n.14 (1st Cir. 1992) ("The preference rules in $\S 547$ (b) ultimately are concerned with fostering equality of treatment among creditors of the same class.").

22. 11 U.S.C. $\S 365$ (2012).

23. See id. (establishing that the debtor "may" assume or reject "any executory contract," thereby providing the debtor with the discretion to pick and choose which contracts to assume or reject).

24. See NLRB v. Bildisco \& Bildisco, 465 U.S. 513, 528 (1984) (observing that "the authority to reject an executory contract is vital to the basic purpose to a Chapter 11 reorganization, because rejection can release the debtor's estate from burdensome obligations that can impede a successful reorganization"). 


\section{The Concept of Path Dependence}

\section{A. Defining Path Dependence}

Path dependence is a term describing sequential processes that evolve gradually in "a direction that is [determined and] influenced by previous [stages] in the process": 25

In broad terms, "path dependence" means that an outcome or decision is shaped in specific and systematic ways by the historical path leading to it. It entails, in other words, a causal relationship between stages in a temporal sequence, with each stage strongly influencing the direction of the following stage. At the most basic level, therefore, path dependence implies that what happened at an earlier point in time will affect the possible outcomes of a sequence of events occurring at a later point in time. ${ }^{26}$

For example, an 18th century fur trader, intent on avoiding wolves and other dangers, may cut a winding path through the woods. ${ }^{27}$ Later travelers follow this path, and in time it becomes a road. ${ }^{28}$ As generations pass, the road becomes paved, and houses and industry are erected alongside. ${ }^{29}$ Although the dangers that affected the fur trader are long gone, few question the road's inefficiently winding route. ${ }^{30}$ And any who do question it could be stymied by the now immense cost of straightening the road, which (among other things) would require moving housing and industry; resources invested in the original road and its surroundings may well render the paving of a straight new road too costly. ${ }^{31}$ Path dependence is not restricted to road

25. Bradley A. Hansen \& Mary Eschelbach Hansen, The Role of Path Dependence in the Development of US Bankruptcy Law, 1880-1938, $3 \mathrm{~J}$. INSTITUTIONAL ECON. 203, 206 (2007).

26. Oona A. Hathaway, Path Dependence in the Law: The Course and Pattern of Legal Change in a Common Law System, 86 Iowa L. REv. 601, 603-04 (2001) (emphasis added) (citation and internal quotation marks omitted).

27. See Mark J. Roe, Chaos and Evolution in Law and Economics, 109 HARV. L. REV. 641, 643-44 (1996) [hereinafter Roe, Chaos] (providing the example originally).

28. Id.

29. Id.

30. Id.

31. Id. at 643 . 
development, but is widespread. ${ }^{32}$ A "range of technological, economic, social, and political arrangements, once in place," can

generate patterns of costs and benefits such that rational actors prefer to maintain the status quo even if an alternative might provide higher aggregate returns in the long run. Actors support the status quo not because change stands to generate some costs-which is true of almost all changes-but because change imposes significant net costs at least in the short term. The longer actors operate within such a status quo, the more any shift to an alternative is unattractive. Initial choices are thus "locked in." 33

\section{B. Legal Path Dependence}

The evolution of legal rules through legislative accretion can likewise be path dependent if earlier legislated rules affect the nature of later legislated rules:

[Many scholars] describe changes in law as being "path dependent" in that, at any moment, law's position along its path of change is the result of many prior choices of direction at forks along the way. ${ }^{34}$

This can occur, for example, when "changes in organized interest groups," "constituent interests," or "party influence" affect subsequent legislation. ${ }^{35}$

In the earlier fur-trader example, path dependence occurred because the resources invested in the original road and its surroundings rendered the paving of a straight new road too costly. ${ }^{36}$ Legal path dependence occurs when an initial path effectively blinds lawmakers to alternative paths. This blindness

32. Cf. Gerard Alexander, Institutions, Path Dependence, and Democratic Consolidation, 13 J. TheORETICAL POL. 249, 254 (2001) (observing path dependence in the decision-making of political institutions as well as major policy initiatives and state structures).

33. Id. (citations omitted).

34. J.B. Ruhl \& Harold J. Ruhl, Jr., The Arrow of the Law in Modern Administrative States: Using Complexity Theory to Reveal the Diminishing Returns and Increasing Risks the Burgeoning of Law Poses to Society, 30 U.C. DAVIS L. REV. 405, 415 (1997).

35. Hausen \& Hansen, supra note 25 , at 206-07.

36. See supra note 31 and accompanying text (referring back to and introducing the original example). 
can occur, for example, when legislative patterns are locked-in due to informational and political burdens.

Informational burdens arise when the choice of one legislative course of action makes future assessments of alternative courses harder; actors become used to the "normal" state of affairs and find it hard to change course. ${ }^{37}$ Political burdens are created when groups or institutions sympathize with earlier legislative choices and wield their influence to maintain and perhaps magnify the patterns created by those choices. ${ }^{38}$ And that in turn can further increase the influence and political power of those groups or institutions, thereby further locking in and magnifying the patterns: [R]ule-driven path dependence might arise from interest group politics. ... If the initial pattern provides one group of players with relatively more wealth and power, this group would have a better chance to have... rules that it favors down the road. Positional advantages inside firms will be translated into positional advantages in a country's politics. And this effect on ... rules will reinforce the initial patterns . . . .39

Informational and political burdens discourage alternative views. ${ }^{40}$ Parties "do not know enough about the other path and ... just thinking about change clashes with our path-induced perception of 'normal' mechanisms. The status quo therefore persists." 41 Professor Mark J. Roe thus argues that the emergence of the decentralized corporate ownership model in the United States blinded policymakers to the alternative models in existence, such as the German and Japanese models of ownership through powerful financial institutions. ${ }^{42}$

37. Roe, Chaos, supra note 27 , at 652 .

38. Id. ("Incumbents usually wield their influence to maintain themselves and to stifle upstarts and change.").

39. Lucien Arye Bebchuk \& Mark J. Roe, A Theory of Path Dependence in Corporate Ownership and Governance, 52 STAN. L. REV. 127, 131 (1999).

40. J.B. Ruhl \& James Salzman, Mozart and the Red Queen: The Problems of Regulatory Accretion in the Administrative State, 91 GEO. L.J. 757, 785-88 (2003) (describing ways in which public choice theory defeats effective change in agency rule making).

41. Roe, Chaos, supra note 27 , at 651 .

42. Id. at 647 . 


\section{Evolution of the Bankruptcy-Law Safe Harbor for Derivatives}

The special treatment of derivatives in bankruptcy exemplifies legal path dependence. As explained below, it is an outcome of decades of sustained industry pressure on Congress to exempt the derivatives market from the reach of the Bankruptcy Code, with each exemption serving as a historical justification for subsequent broader exemptions.

\section{A. The 1978 Bankruptcy Code}

The initial exemptions-which were included in 1977 in the bill that became the Bankruptcy Code-were promoted by an attorney with ties to the derivatives industry, Stuart D. Root. Root was invited to testify before a U.S. Senate subcommittee ${ }^{43}$ and suggested that Congress grant commodities brokers authority to "close out" an insolvent customer's account in order to prevent "a potential domino effect." $44 \mathrm{He}$ argued that the commodities futures market "is a delicate, if not fragile, system depending for its success on capital adequacy of the many participants," 45 and unless the Bankruptcy Code addressed this fragility, "the system will remain unnecessarily exposed."46

As sole evidence of this fragility, Root cited a court case, Geldermann and Company, Inc. v. Lane Processing, Inc. ${ }^{47}$ In that case, when a commodities-market trader failed to meet margin calls, the trader's broker liquidated a short position in the

43. Mr. Root was invited to testify in front of the Senate Subcommittee on Improvements in Judicial Machinery. S. REP. No. 95-989, at 2 (1977), reprinted in 1978 U.S.C.C.A.N. 5787, 5788. He was "an attorney practicing law in New York City as a member of the firm of Cadwalader, Wickersham \& Taft [who, in the course of his practice,] had occasion to counsel institutional investors concerning aspects of the bankruptcy laws." Bankruptcy Reform Act of 1978: Hearings on S. 2266 and H.R. 8200 Before the Subcomm. on Improvements in Judicial Machinery of the S. Comm. on the Judiciary, 95th Cong. 521 (1977) (statement of Stuart D. Root, Esq., New York, New York) [hereinafter Root Testimony], available at https://archive.org/details/bankruptcyreform1978unit.

44. Id. at 524 .

45. Id.

46. Id.

47. 527 F.2d 571 (8th Cir. 1975); Root Testimony, supra note 43, at 524 (citing Geldermann). 
trader's account and sued the trader for the remaining balance due.48 The trader counterclaimed that the rules of the Commodities Futures Exchange, which permitted a broker to liquidate positions of customers that do not meet margin calls, were unconscionable and hence unenforceable. ${ }^{49}$ Rejecting the counterclaim, the court noted that liquidation rules

promoted the interest and protection of the commission merchants, their customers and the investing public as a whole. Investors or speculators who have failed to deposit sufficient maintenance margins may have insufficient financial resources to withstand substantial losses on the market and, if so, continued trading on that account is a financial risk for the commission merchant, and ultimately for the commodities exchange if the loss suffered by the commission merchant exceeds its capital account. ${ }^{50}$

Root did not explain in his testimony before the Senate, however, why the inability of a commodities broker to freely close out an insolvent customer's account-or why a requirement that the broker seek court permission to close out that account-could cause the domino effect he warned against. 51

Nonetheless, Congress followed Root's suggestion and included several narrow exemptions in the Bankruptcy Code. The Code included, for example, an exemption from the power of a trustee-in-bankruptcy to avoid, as a preferential transfer, margin payments made by or to a commodity broker and liquidations of commodity contracts. ${ }^{52}$ The Code also included a limited exemption from the automatic stay for setoff of mutual debts and claims in connection with "commodity futures contracts, forward commodity contracts, leverage transactions, options, warrants, rights to purchase or sell commodity futures contracts or

48. Geldermann, 527 F.2d at 574.

49. Id.

50. Id. at 577.

51. See Stephen J. Lubben, Repeal the Safe Harbor, 18 AM. BANKR. INST. L. REV. 319, 329-30 (2010) [hereinafter Repeal] (claiming that this question has still not been answered by the derivatives industry).

52. See Pub. L. No. 95-598, § 764(c), 92 Stat. 2549, 2619 (codified as amended at 11 U.S.C. $\$ 764(a)$, (b) (2012)) ("[T] the trustee may not avoid a transfer that is a margin payment to or deposit with a commodity broker or forward contract merchant or is a settlement payment made by a clearing organization and that occurs before the commencement of the case ...."). 
securities, or options to purchase or sell commodities or securities." 53 This exemption was "limited" because the legislative history indicated an intention that the debtor may request the bankruptcy court, on a case-by-case basis, to hold a hearing on whether a particular setoff might harm the bankruptcy-in which case it would be stayed. ${ }^{54}$ Congress was initially unwilling, in other words, to provide derivatives counterparties with a blanket exemption from the automatic stay. ${ }^{55}$ As will be shown, these exemptions were later used as precedent to justify broader exemptions, which in turn served as precedent for increasingly broader exemptions. ${ }^{56}$

53. Pub. L. No. 95-598, $\S 362(b)(6), 92$ Stat. 2549, 2571 (codified as amended at 11 U.S.C. $\S 362(\mathrm{~b})(6)(2012)$ ).

54. S. REP. No. 95-989, at 51 (1977), reprinted in 1978 U.S.C.C.A.N. 5787, 5837; H.R. REP. No. 95-595, at 342 (1978), reprinted in 1978 U.S.C.C.A.N. 5963, 6298 .

55. As will be discussed, see infra Part IV.B, subsequent amendments to the Bankruptcy Code included language that changed this limited exemption to a more blanket exemption. See, e.g., Whyte v. Barclays Bank PLC, No. 12-civ5318(JSR), 2013 WL 2489925, at *4 (S.D.N.Y. June 11, 2013) ("Both the facial breadth of these provisions, and the corresponding legislative history, make plain that Congress intended to place swap transactions totally beyond the inherently destabilizing effects of a bankruptcy and its attendant litigation." (emphasis added)).

56. Indeed, " $[t]$ he special treatment of derivative contracts is just one more example of the increasing tendency for special interest legislation to erode the efficiency of [C]hapter 11 by piecemeal repeal of the chapter." Stephen J. Lubben, Derivatives and Bankruptcy: The Flawed Case for Special Treatment, 12 U. PA. J. Bus. L. 61, 63-64 (2009) [hereinafter Derivatives and Bankruptcy]. This gradual process, by which financial instruments proliferate and grow over time in the shadow of certain legal arrangements, without systematic examination of consequences, is not unique to the Bankruptcy Code or the derivatives market. Others have identified similar occurrences that weakened the financial system and contributed to the 2007-2009 financial crisis. See, e g., Jennifer S. Taub, Other PeOple's Houses: How Decades of Bailouts, CaPtive Regulators, and Toxic Bankers MADE Home MorTGages a Thrilling Business 222-46 (2014) (accusing various participants in the law- and rule-making processes of being "legal enablers of the toxic chain" that led to the economic crisis); Kathryn Judge, Fragmentation Nodes: A Study in Financial Innovation, Complexity, and Systemic Risk, 64 STAN. L. REV. 657, 661 (2012) ("The incremental nature of this process is critical to understanding how these transactions became so complex and why that complexity was not subject to greater regulatory or market scrutiny prior to the 2007-2009 financial crisis."). 


\section{B. The 1982 Amendment}

Amendments to the Bankruptcy Code, starting in 1982, further expanded the safe harbor exemptions. The potential "domino" (sometimes called "ripple") effect argumentessentially, concern about systemic risk-was repeatedly raised as a justification for introducing these exemptions. ${ }^{57}$

The 1982 amendment expanded the safe harbor beyond commodities futures markets. The amendment added narrow exemptions from the automatic stay for "mutual debt and claim" setoff by securities counterparties and liquidation of derivatives contracts. ${ }^{58}$ The new "contractual right to liquidate" also accorded certain counterparties this power to terminate and liquidate derivatives contracts upon insolvency of the debtor, thereby circumscribing the Bankruptcy Code's ban on ipso facto clauses. ${ }^{59}$

The 1982 expansion of the safe harbor was viewed by Congress as merely continuing the goal of preventing systemic risk. ${ }^{60}$ But that risk, which was described in 1978 as a "potential domino effect," 61 was now termed a threat of market collapse. ${ }^{62}$ Also, the 1982 legislative history does not reference the 1978 legislative intention that part of the safe harbor would be construed only as a shift of legal burden, with its actual application being developed by judicial analysis. ${ }^{63}$ The 1982

57. Stephen Adams discusses the centrality of systemic risk to the safe harbor justifications historically and notes both the unanimity and vagueness of the discussions. Stephen D. Adams, Derivative Exemptions in Bankruptcy and Dodd Frank: A Structural Analysis 9-13 (Harvard Law School, Financial Crisis Working Papers Series, 2014), available at http://ssrn.com/abstract=2348828.

58. Pub. L. No. 97-222, 96 Stat. 235, 236 (1982) (amending $§ 362(b)(6)$ ofand adding $\S \S 555-56$ to-the Bankruptcy Code).

59. Jonathon Keath Hance, Derivatives in Bankruptcy: Lifesaving Knowledge for the Small Firm, 65 WASH. \& LEE L. REV. 711, 739-40 (2008). 583.

60. H.R. REP. No. 97-420, at 1 (1982), reprinted in 1982 U.S.C.C.A.N. 583,

61. Root Testimony, supra note 43 , at 524 .

62. See H.R. REP. No. 97-420, at 1 (1982), reprinted in 1982 U.S.C.C.A.N. 583,583 (deeming the potential risk to "threat[en] the collapse of the affected market").

63. See Lubben, Derivatives and Bankruptcy, supra note 56, at 63-64 (describing the 1978 legislative intention that courts should determine, on a case-by-case basis, whether a particular action which may be harming the estate should be stayed). 
amendment thus signified a significant next step in a gradual process toward the complete severance of the derivatives market from debtor protections in bankruptcy. As we next discuss, this perception shift-from what previously was seen as merely a potential risk, to a real systemic threat-accompanied all subsequent amendments to the Bankruptcy Code's safe harbor.

\section{The 1984 Amendment}

In 1984 Congress added repurchase agreements to the classes of derivatives exempted from the Bankruptcy Code's automatic stay. ${ }^{64}$ The amendment also broadened the range of parties entitled to the exemptions beyond derivatives-market actors. Thus, the safe harbor exemption was granted to a "repo participant," i.e., any party to a repurchase agreement. ${ }^{65}$ On the other hand, the amendment imposed a time limit in the definition of "repo participant," providing the safe harbor only to "an entity that, on any day during the period beginning 90 days before the date of the filing of the petition, has an outstanding repurchase agreement with the debtor."66

A repurchase agreement was narrowly defined as well, and the amendment restricted the exemptions to agreements for the transfer of certificates of deposit, bankers' acceptances, or U.S. government securities. ${ }^{67}$ In contrast to the 1982 restrictive definition of "contractual right to liquidate," the 1984 amendment introduced a flexible meaning to the term, referring not only to a rule or bylaw of an exchange, a securities association, or a clearing agency but also to "a right, whether or not evidenced in writing, arising under common law, under law merchant or by reason of normal business practice."68 In addition, the authorization to liquidate a repurchase agreement

64. Bankruptcy Amendments and Federal Judgeship Act of 1984, Pub. L. No. $98-353, \S 391,98$ Stat. 333 (amending $\S 362$ of the Bankruptcy Code).

65. Pub. L. No. 98-353, § 391, 98 Stat. 333, 365 (redefining definitional terms to a broader extent and amending $\S 101(36)$ of the Bankruptcy Code).

66. Id.

67. Id.

68. Id. $§ 559,98$ Stat. $333,366$. 
notwithstanding the automatic stay included permission to foreclose on the underlying collateral. ${ }^{69}$

This authority to go against the underlying collateral exceeded previous contractual rights to liquidate commodities and forward transactions that involved the writing of an offsetting position. ${ }^{70}$ It paved the way for subsequent amendments that allowed derivatives counterparties a broad right of foreclosure on security interests, notwithstanding bankruptcy of the debtor (which had granted the security interest). The 1984 amendment thus can be seen as continuing a shift in Congress's approach towards the derivatives market. While the 1978 Bankruptcy Code and the 1982 amendment were relatively restrained in exempting derivatives counterparties from the Code's protections, the 1984 amendment moved toward a broader exemption of derivatives in bankruptcy. ${ }^{71}$

\section{The 1990 Amendment}

With the ongoing development of financial markets and new financial instruments, the derivatives industry became concerned that the existing safe harbor would be insufficient. ${ }^{72}$ In 1988, Senators DeConcini and Grassley introduced a bill to amend the Bankruptcy Code regarding swap agreements. ${ }^{73}$ The bill was endorsed by the International Swaps and Derivatives Association (ISDA), which urged Congress to eliminate the risk that market liquidity would be restricted due to application of the Bankruptcy

69. Id.

70. The "contractual right to liquidate" derivatives contracts previously granted to derivatives counterparties "was limited to the right to close out an open position." Hance, supra note 59, at 742 (referring to Pub. L. No. 97-222, $\S 556$, 96 Stat. 235,237 , which stated that the "contractual right to liquidate" does "not constitute the right to transfer cash, securities, or property held with respect to such contracts"). Due to the nature of repurchase agreements (essentially collateralized loans), this restriction was not included in the 1984 amendment.

71. See id. ("[J] ust two years after the 1982 Amendments, Congress widened the scope of the automatic stay exemptions ....").

72. Morrison \& Riegel, supra note 10, at $647 \mathrm{nn} .40$ \& 43 (alluding to worries among industry groups, practitioners, and members).

73. See generally S. 2279, 100th Cong. (1988). 
Code to swap transactions, "particularly in periods of volatility."74 In a classic example of interest-group politics intervening to lock in path-dependent legislative patterns, ISDA noted that "Congress has for many years recognized the need for certainty and speed in the treatment of securities and other similar financial transactions in bankruptcy," and that former amendments to the Bankruptcy Code with regard to securities, commodities, and repurchase agreements "worked well in practice and have provided needed certainty." "75 ISDA argued that the requested new protections "closely parallel[ed]" those provided by the 1982 and 1984 amendments. ${ }^{76}$

The proposed amendment deviated, however, from the former amendments at least in one aspect: it explicitly exempted netting. Derivatives are traded between parties according to rules established in a master agreement. The master agreement serves as a contractual framework for multiple transactions, providing "the general terms of the agreement between counterparties with respect to general questions such as credit support arrangements, netting, collateral, definition of default and other termination events, calculation of damages (on default), documentation, and so forth."77 ISDA's standard master agreement provided that all swap transactions between parties are terminated and netted in the event of a default. ${ }^{78}$ Without an explicit exemption in the Bankruptcy Code, the derivatives industry feared that the practice of netting would be prevented by the automatic stay. The 1990 amendment provided this exemption. A "swap agreement" was expansively defined, encompassing any conceivable form of a swap transaction, any option to enter a swap transaction, any

74. Bill Pertaining to Title 11 of the United States Code, The Bankruptcy Code: Hearings on S. 1626, S. 1358, S. 1863, and S. 2279 Before the Subcomm. on Courts and Administrative Practice of S. Comm. on Judiciary, 100th Cong. 672 (1988) (statement of the International Swap Dealers Association in Support of S. 2279) [hereinafter Statement of ISDA].

75. Id.

76. Id.

77. Robert R. Bliss \& George G. Kaufman, Derivatives and Systemic Risk: Netting, Collateral, and Closeout, 2 J. Fin. STABILITY 55, 58 (2006).

78. Netting allows "any potential liability of a defaulting party [to be] reduced by the value of any swap transaction that favored that party." Statement of ISDA, supra note 74 , at 674 . 
combination of the foregoing, and even a master agreement "for any of the foregoing together with all supplements."79

The 1990 amendment nonetheless continued, as in former amendments, a somewhat transaction-specific expansion of the safe harbor. This transaction-specific approach fostered an intricate patchwork of rules, which led to market confusion. ${ }^{80}$ The exemptions sometimes lacked coherence, with rights available to counterparties differing from one financial product to another without clear economic rationale. ${ }^{81}$

\section{E. The Bankruptcy Abuse Prevention and Consumer Protection Act of 2005}

By the time a further expansion to the safe harbor was considered in 2005, the 1998 near failure of the Long-Term Capital Management hedge fund (LTCM) provided a dramatic example of the possible association between derivatives and systemic risk. ${ }^{82}$ LTCM started its operations in early $1994 .{ }^{83} \mathrm{Its}$ portfolio increased rapidly, and by the end of 1997, LTCM was already "significantly larger than any other reporting hedge fund family at that time." 84 By August 1998, after only four years of operation, LTCM's gross notional amounts of derivatives contracts exceeded $\$ 1.4$ trillion. ${ }^{85}$ LTCM's rapid growth in trading was contrasted with a gradual thinning of its capital and assets

79. Pub. L. No. 101-311, § 101, 104 Stat. 267.

80. See Morrison \& Riegel, supra note 10, at 646-47 ("None of these transactions was defined by the Code; a judge was presumably expected to rely on standard market definitions.").

81. See id. at 647-48 ("As a result, a pension fund or oil company might find itself protected with respect to swaps but unprotected with respect to forwards with the very same party.").

82. See Bliss \& Kaufman, supra note 77, at 66 n.30 (noting "concerns that failure of LTCM would likely have resulted in severe market disruptions and significant losses to direct counterparties and other market participants").

83. President's Working GrP. on Fin. Mkts., Hedge Funds, Leverage, AND THE LEssons OF LONG-TERM CAPITAL MANAGEMENT 10 (1999), http://www.treasury.gov/resource-center/fin-mkts/Documents/hedgfund.pdf [hereinafter PWG REPORT].

84. Id. at 29 .

85. Id. at 11-12. 
base, resulting in a leverage ratio of more than 25:1 on the eve of the events that caused its near collapse. ${ }^{86}$

An unexpected series of market movements during August of 1998 - due to devaluation of the Russian Ruble - caused LTCM to suffer equity losses of over 50\%.87 LTCM found it harder and harder to raise capital as its condition deteriorated. 88 By midSeptember 1998, the possibility of LTCM's collapse became a reality, and markets were frantic about its implications. ${ }^{89}$

In an effort to prevent a financial disaster, the New York Federal Reserve organized a creditors' bailout of LTCM.90 Grouping together fourteen of the most concerned LTCM counterparties, the N.Y. Federal Reserve orchestrated an out-of-court recapitalization scheme under which the firms would inject $\$ 3.6$ billion in new equity into LTCM in return for $90 \%$ of the ownership interest in the firm. ${ }^{91}$ The recapitalization scheme was accepted by LTCM, and the crisis was resolved with LTCM primary counterparties assuming responsibility for allowing "the hedge fund to build up its positions in the first place."92

In April 1999, the President's Working Group on Financial Markets (the PWG) issued a report on the LTCM crisis (the PWG Report). Among other things, the PWG Report observed that if LTCM had defaulted, the use of close-out netting rights by derivatives counterparties that are not subject to the automatic stay would have mitigated counterparty losses and reduced the likelihood of instability in the financial markets. ${ }^{93}$ Therefore, it argued, "[t]he ability to terminate most financial market contracts upon an event of default is central to the effective management of market risk by financial market

86. Id. at 12 .

87. Id.

88. See id. at $12-13$ (noting that LTCM's previously flexible credit arrangements became more rigid, which exacerbated LTCM's liquidity problem).

89. See Rhett G. Campbell, Financial Markets Contracts and BAPCA, 79 AM. BANKR. L.J. 697, 699 (2005) (noting that, given LTCM's size, its collapse could have widespread effects on the market).

90. See Edwards \& Morrison, supra note 20, at 100 (claiming that LTCM would have collapsed without the Federal Reserve's intervention).

91. PWG REPORT, supra note 83, at 13-14.

92. Id. at 14.

93. See id. at 19 (arguing that these rights limit the potential size of credit exposures, thus promoting market stability). 
participants . ..."94 Terminating derivatives transactions alone is not enough; termination "goes hand in hand with netting," 95 which serves as a "domino effect" constrainer because it reduces the exposure of counterparties to a failed debtor. ${ }^{96}$ Based on these findings, the PWG urged Congress to further expand the Bankruptcy Code safe harbor to improve market stability. ${ }^{97}$

The PWG's call for a broadening of the safe harbor was not left unheard. The recommendations of PWG were incorporated into an amendment to the Bankruptcy Code as part of the Bankruptcy Reform Act of $1999,^{98}$ ultimately enacted as the Bankruptcy Abuse Prevention and Consumer Protection Act of 2005 (BAPCA). ${ }^{99}$ BAPCA gave free rein to derivatives counterparties to completely circumscribe the Bankruptcy Code's

94. Id.

95. Id. at 20 .

96. Id.

97. See id. at 26 (arguing that such expansion would prevent a single insolvency from triggering multiple insolvencies throughout the market).

98. See Bankruptcy Revision: Hearing on H.R. 833 Before the Subcomm. on Commercial \& Admin. of the H. Comm. on the Judiciary, 106th Cong. 18 (1999) (statement of Rep. Leach) ("Title X contains legislative proposals forwarded to Congress by the nation's financial regulators in order to guard against systemic risk to the nation's financial system .... The specific proposals are derived from the President's Working Group on Financial Markets."); Bankruptcy Revision: Hearing on H.R. 833 Before the Subcomm. on Commercial \& Admin. of the H. Comm. on the Judiciary, 106th Cong. 31 (1999) (statement of Rep. Roukema)

This Title will harmonize banking and bankruptcy law with respect to the netting of financial contracts. It was produced by the President's Working Group on Financial Markets and is strongly supported by the Federal Banking agencies. I support Chairman Leach on this and appreciate that the Committee has included this Title in the Bankruptcy Bill.

Bankruptcy Revision: Hearing on H.R. 833 Before the Subcomm. on Commercial \& Admin. of the H. Comm. on the Judiciary, 106th Cong. 347 (1999) (statement of Oliver Ireland, Assoc. Gen. Counsel, Fed. Reserve Sys.)

Title $\mathrm{X}$ includes a number of proposed amendments to the Federal Deposit Insurance Act and the Bankruptcy Code, as well as other statutes relating to financial transactions. Most of these provisions incorporate or are based on amendments to these statutes that were endorsed by the President's Working Group on Financial Markets. The Board supports enactment of the provisions recommended by the President's Working Group. Enactment of these provisions would reduce uncertainty in the financial markets.

99. Pub. L. No. 109-008, 119 Stat. 23 (codified as amended at 11 U.S.C. $\S \S 101-1502(2005))$. 
automatic stay and preference rules. First, it expanded the Code's definitions of "securities contract,"100 "commodities contract,"101 "forward contract,"102 "repurchase agreement,"103 and "swap agreement"104 to include a long list of specific types of known derivatives, as well as any other similar agreement or transaction, ${ }^{105}$ any combination of the defined derivative transaction, ${ }^{106}$ any option to enter a derivative transaction of the kind defined in the specific clause, ${ }^{107}$ a master agreement that provides for the defined derivative transaction, or any security agreement or arrangement or other credit enhancement related to the defined transaction. ${ }^{108}$ The purpose was to enable the safe harbor to encompass any future version of existing derivative transaction and "to avoid the need for future amendments." 109

BAPCA also expanded the safe harbor by creating a new category of parties eligible for safe harbor protection. ${ }^{110}$ In order to make certain that closeout and netting would be available to derivatives counterparties even if they did not fit neatly into one of the specific definitions available in the Code, BAPCA created a general definition of "Financial Participant" to include any entity that, at the time it enters a securities contract, commodity contract, swap agreement, repurchase agreement, or forward contract, or at the time of the filing of its bankruptcy petition, holds a total of $\$ 1$ billion in notional or actual principal amount of derivatives transactions, or gross mark-to-market positions of not less than $\$ 100,000,000$ (aggregated across counterparties), in one or more agreements with the debtor on any day during the prior

100. Id. $\S 901$ (b) (amending the definitional provisions of 11 U.S.C. $\S 101$ ).

101. Id. § 901(c) (same).

102. Id. $\S 901$ (d) (same).

103. Id. $\S 901$ (e) (same).

104. Id. $\S 901$ (f) (same).

105. Id. $\S \S 907,101(25), 101(53 \mathrm{~B}), 741(7), 761(4)$. For some reason, repos did not enjoy this specific expansion.

106. Id. $\S \S 907,101(25), 101(47), 101(53 \mathrm{~B}), 741(7), 761(4)$.

107. Id. $\S 901(\mathrm{f})(1)(\mathrm{vi})$.

108. Id. $\S 901(\mathrm{f})(1)$.

109. Campbell, supra note 89 , at 704 .

110. See Hance, supra note 59, at 757-58 (noting that Congress created a "catchall category" for "financial participants"). 
fifteen month period. ${ }^{111}$ The intention was to include very large institutions whose collapse would pose imminent threat to the sustainability of the market. 112

BAPCA also introduced the concept of cross-product netting into the Bankruptcy Code. ${ }^{113}$ Adding the terms "master netting agreement" and "master netting agreement participant" to the list of contractual relationships and parties exempted from the automatic stay, 114 it enabled derivatives counterparties to document a wide variety of derivatives transactions and to execute netting between different products traded with the debtor. ${ }^{115}$

These expansions to the safe harbor-which as always, were justified as a means to reduce systemic risk ${ }^{116}$-were not unopposed. The National Bankruptcy Conference, which includes some of the nation's leading bankruptcy scholars and practitioners, advised Congress's Subcommittee on Commercial and Administrative Law that " $[t]$ here is no indication that the absence of such cross-product netting features has led to widespread difficulties or systemic disruptions in the financial markets for such products."117 Professor Randal Picker of the

111. See Bankruptcy Abuse Prevention and Consumer Protection Act of 2005, Pub. L. No. 109-8, § 907, 119 Stat. 23 (codified at 11 U.S.C. $\S 101(22 \mathrm{~A})$ ) (defining the new category criteria for "financial participants").

112. See Hance, supra note 59 , at 758 (noting that the new category came from a concern for "the possibility of systemic risk if large financial participants" faced challenges in filing).

113. See Morrison \& Riegal, supra note 10, at 649 (noting that "the Act creates a new super-category" to include cross-product netting). In practice, cross-product netting was not new to the industry. However, prior to BAPCA, it was not clear whether this practice is permitted by law. BAPCA solved this uncertainty by providing a legislative right to cross-product netting in bankruptcy. Id. at 647,649 .

114. See 11 U.S.C. $\S \S 101(38 \mathrm{~A}),(38 \mathrm{~B}), 362(\mathrm{~b})(27)$ (2012) (defining both terms and providing for an exemption from the automatic stay for the "exercise ... of any contractual right" under a security agreement associated with a master netting agreement).

115. H.R. REP. No. 109-31, pt. 1, at 130-31 (2005) (describing the purpose and function of the new category for "financial participants").

116. See id. at 130 (noting the inclusion of the new category to limit the potential impact of insolvencies upon other market participants).

117. Bankruptcy Reform Act of 1999 (Part III): Hearing on H.R. 833 Before the Subcomm. on Commercial and Administrative Law of the House Comm. on the Judiciary, 106th Cong. 179 (statement of Randal Picker, on behalf of the 
National Bankruptcy Conference also warned Congress, although to no avail, that "master netting could deprive a debtor of muchneeded cash collateral, which in some instances may lead to conversion and liquidation to the detriment of other creditors [and therefore that] the master netting provisions should be deleted." 118

\section{F. The Financial Netting Improvements Act of 2006}

Notwithstanding the expectation that BAPCA's expansion of the safe harbor would be sufficient, ${ }^{119}$ Congress once again amended the Bankruptcy Code in 2006.120 This is its most recent effort to "update the [safe harbor] language to reflect current market and regulatory practices, and help reduce systemic risk in the financial markets by clarifying the treatment of certain financial products in cases of bankruptcy or insolvency." 121

The 2006 amendment focused, among other things, on improving "the netting process for financial contracts... by strengthening and clarifying the enforceability of early termination and close-out netting provisions." 122 The belief was that stronger netting capacity can help to enhance market stability; counterparties of a distressed debtor will have less incentive to terminate their positions because they can net and thereby reduce their exposure to the debtor's credit risk. ${ }^{123}$ Little thought appears to have been given to whether stronger netting might backfire by motivating increased counterparty concentration, thereby increasing systemic risk. ${ }^{124}$

National Bankruptcy Conference).

118. Id. at 177 .

119. See Campbell, supra note 89 , at 74 (discussing the hope that the BAPCA of 2005 would not need further amendments).

120. Financial Netting Improvements Act of 2006, Pub. L. No. 109-390, 120 Stat. 2692 (2006).

121. H.R. REP. No. 109-648, pt. 1, at 1-2 (2006).

122. Id. at 2 .

123. See Bliss \& Kaufman, supra note 77 , at 62 (discussing the market effects of netting).

124. See infra notes $168-70$ and accompanying text (observing that stronger netting can motivate increased counterparty concentration). 


\section{Is the Derivatives Safe Harbor Path Dependent?}

The foregoing discussion shows that the derivatives safe harbor is at least largely path dependent. Recall that legal path dependence occurs when an initial path blinds lawmakers to alternative paths. ${ }^{125}$ This blindness can occur when legislative patterns are locked-in due to informational and political burdens, which discourage alternative views. ${ }^{126}$

The origin of the path dependence was the lobbyist-sponsored limited exemption, included in the bill that became the Bankruptcy Code, for the allegedly fragile commodities futures market. ${ }^{127}$ The untested justification for the initial exemptionconcern about systemic risk-was reiterated for subsequent expansions of the safe harbor, often without questioning, much less careful investigation, of the merits of the expansions to protect against systemic risk. ${ }^{128}$ Thus, rights that were initially provided to specific counterparties were later granted to any counterparty. ${ }^{129}$ Exemptions from certain procedures given to one counterparty were later given to another, with no questioning of the need for or the consequences of such actions. ${ }^{130}$ As the legislative history demonstrates, Congress usually assumed that an expanding safe harbor would help protect against systemic risk, and with each passing amendment, that assumption became

125. See supra notes 36-38 and accompanying text (discussing path dependence generally).

126. See supra notes 36-42 and accompanying text (discussing the patterns of legal path dependence).

127. See James Mahoney, Path Dependence in Historical Sociology, 29 THEORY \& SOC'Y 507, $513(2000)$ (observing that "once a particular option is selected it becomes progressively more difficult to return to the initial point when multiple alternatives were still available"); supra notes 43-52 and accompanying text (describing how Mr. Root's testimony altered Congress's legislative trajectory).

128. See PWG REPORT, supra notes 92-96 and accompanying text (discussing the effect of lobbying on the development of legislation). The PWG Report constituted the most important study of the merits of the safe harbor. That Report, however, has been criticized. See infra notes 186-92 and accompanying text (arguing that unrestricted close-out netting, the Report's central recommendation, can trigger the equivalent of a bank run).

129. See supra notes 99-109 and accompanying text (discussing the expansion of rights through amendments to the Bankruptcy Code).

130. See id. (discussing the Congressional response to the PWG report). 
more entrenched as a truth. ${ }^{131}$ This reflects an informational blindness, discouraging alternative views. ${ }^{132}$ Building on this informational blindness, the derivatives industry succeeded to completely exempt itself from the restrictions of the Bankruptcy Code. ${ }^{133}$

The informational blindness was almost certainly exacerbated by both the complexity of derivatives and uncertainty over how systemic risk is created and transmitted. ${ }^{134}$ Conceptualizing alternative paths is always difficult, and the more complex and uncertain the alternatives the more difficult it is. ${ }^{135}$ From its inception, the discussion in Congress of the safe harbor was overshadowed by these complexities and uncertainties, as well as imprecision about the causal relationship between derivatives and systemic risk. ${ }^{136}$ Being concerned about the latter, members of Congress tended to see what they expected to see, ${ }^{137}$ the expectation in this case being

131. See, e.g., Statement of ISDA, supra note 74 , at 674 (observing that "Congress has for many years recognized" the need for the safe harbor).

132. See supra Part III.B (discussing legal path dependence).

133. See supra notes $110-15$ and accompanying text (discussing the almost complete exemptions from bankruptcy offered by the safe harbor provisions for derivatives parties).

134. See Roe, Chaos, supra note 27, at 651 (observing that one cause of the information burden is that decision-makers do not know enough about alternative paths).

135. See Ruhl \& Ruhl, supra note 34 , at 452

Society is also faced with the unpredictable ripple effects the law's failure will have on the proper functioning of many other laws and, consequently, the other social institutions with which the laws are intertwined. Structural complexity breeds vulnerability, which breeds more structural complexity, which breeds more vulnerability, and so on.

136. See Morrison \& Riegel, supra note 10, at 641 (observing that Congress was so intimidated by the complexity of the derivatives market that it directed professional bankruptcy judges to apply a formalistic inquiry that is detached from the transaction's characteristics and is wholly dependent on industry custom); infra notes 164-65 and accompanying text (observing the difficulty of obtaining accurate information about the relationship between derivatives and systemic risk); Adams, supra note 57 (noting in regard to the initial enactment of the safe harbor in the 1978 Bankruptcy Code that "[t]he newness and complexity of derivative instruments were obstacles to full understanding of what they were capable of and how they should be used").

137. See Steven L. Schwarcz \& Lucy Chang, The Custom-To-Failure Cycle, 62 DUKE L.J. 767, 767 (2012) (observing that, being "limited-capacity 
driven by powerful derivatives-industry lobbying pressure. ${ }^{138}$ From a public choice standpoint, no powerful interest groups presented Congress with opposing views. ${ }^{139}$

The safe harbor expansion, accomplished through incremental amendments to the Bankruptcy Code, was accompanied in part by liberal judicial interpretation of the safe harbor's reach. That liberality also appears to be explained by the informational burden. ${ }^{140}$ Courts could not independently investigate, and thus had little choice but to accept, the merits of the systemic risk justification for the safe harbor reflected in the legislative history. ${ }^{141}$

For example, in the In re National Gas Distributors, L.L.C. case, ${ }^{142}$ a trustee-in-bankruptcy alleged that gas supply contracts entered into by the debtor with customers during the year preceding its bankruptcy petition created fraudulent conveyances and therefore should be avoided.143 The customers countered that the contracts were "commodity forward agreements" within the Bankruptcy Code's definition of "swap agreements," and thus were exempt from avoidance. ${ }^{144}$ Looking to the legislative history, the court noted that in enacting the safe harbor, "Congress intended to protect the financial markets" from "the destabilizing effects of bankruptcy."145 Accordingly, the court remanded, noting that the "bankruptcy court gave the definition of 'commodity

information processors," human beings "tend to compensate [in areas of complexity] by relying heavily on ... simplifications of reality that allow us to make decisions in spite of our limited ability to process information" (internal citations omitted)).

138. See infra notes 153-54 and accompanying text (discussing ISDA's rise in prominence and power). The most dominant derivatives-industry lobbying organization was ISDA.

139. See supra notes 116-18 and accompanying text (observing that the leading organization that presented Congress with opposing views was the National Bankruptcy Conference, which consisted of bankruptcy scholars and practitioners).

140. See infra notes 142-46 and accompanying text (noting that the Courts relied on the same information bases as Congress in making decisions).

141. See infra notes $142-46$ and accompanying text.

142. 556 F.3d 247 (4th Cir. 2009).

143. See id. at 249-50 (discussing the factual background).

144. Id. at 250 .

145. Id. 
forward agreement' a more narrow reading than the statute bears." 146

The 2005 expansion of the safe harbor accomplished in BAPCA, which exempted all derivatives transactions (broadly defined) from bankruptcy law, in part reflects a corollary form of a path-dependent informational burden. The pre-BAPCA Bankruptcy Code contained inconsistent definitions of exempted derivatives transactions and parties-an outcome of the gradual path-dependent progression of the exemptions based on the constant emergence of new derivatives and market practices. ${ }^{147}$ That in turn caused additional uncertainty as to which derivatives counterparties and transactions were covered by the safe harbor. ${ }^{148}$ That additional uncertainty created an incentive for Congress to follow ISDA's recommendation and include all derivatives counterparties and transactions in the safe harbor. ${ }^{149}$

To the extent BAPCA's 2005 expansion of the safe harbor was recommended by the PWG Report, issued by the President's Working Group on Financial Markets, ${ }^{150}$ such expansion might not appear to represent legal path dependence. Nonetheless, that Report does not address opposing views such as those of the National Bankruptcy Conference. ${ }^{151}$ Furthermore,

146. Id. at 259. The court further observed that although

these particular contracts were not traded in financial markets-and perhaps were not even assignable- they nonetheless could have an influence on markets in which participants enter into hedging agreements. A business can enter into a forward agreement with a party who then, in reliance on that forward agreement, enters into another contract with yet another market participant, who in turn may enter into even other contracts. And so a simple forward agreement may readily become tied into the broader markets that Congress aimed to protect in BAPCPA.

Id. at 257 .

147. See Morrison \& Riegel, supra note 10, at 646 (discussing the limited exemptions under the "old Code").

148. See id. at 646-47 (discussing the difficulty of interpreting the new provisions).

149. See id. at 648-49 (discussing the expanded definitions under the newer provisions).

150. See supra notes 116-18 and accompanying text (discussing the external influences on Congress during the adoption of the BAPCA).

151. See supra notes 92-93 and accompanying text (discussing the concerns addressed in the PWG Report). 
ISDA played a significant role in the drafting of the relevant provisions of ... [the BAPCA and] worked in "close collaboration" with the President's Working Group on Financial Markets.... ISDA prepared a position paper in 1996 setting forth the need for amendments to the Bankruptcy Code ... and proposing language for many of the provisions eventually amended by BAPCA. ISDA also participated in many of the hearings that led up to the eventual adoption of the provisions that were passed as part of the BAPCA. ${ }^{152}$

Indeed, ISDA's significant influence reflects the fact that as the derivatives industry skyrocketed in size, ${ }^{153}$ lobbyists such as ISDA became much more powerful, creating a political burden that discouraged alternative views. ${ }^{154}$ This parallels the observation that the legislative creation of incumbents "cause[s] changes in the costs and benefits of interest group organization" and "affect[s] the resources available to an interest group [such as ISDA] and thus its ability to provide resources to legislators." 155

152. Brief for the International Swaps and Derivatives Association, Inc. as Amicus Curiae supporting Appellants at 1-2, In re Nat'l Gas Distribs., L.L.C., 556 F.3d 247 (4th Cir. 2009) (No. 07-2105), 2008 WL 412344.

153. The size of the derivatives market grew immensely during the three decades that passed since the initial enactment of the first safe harbor provisions in 1978. See, e.g., Rene M. Stulz, Financial Derivatives: Lessons from the Subprime Crisis, Milken INST. REV., First Quarter 2009, at 61 "Over the last three decades, outstanding derivatives have increased 300-fold."); Waldman, supra note 19, at 1031-32 ("Totaling only $\$ 3$ billion in notional principal in 1982, the market for swaps, the most common form of derivative, has risen over 1200-fold in ten years."); Alan Greenspan, Chairman, Fed. Reserve Bd., Remarks before the Futures Industry Association: Financial Derivatives, (Mar. 19, 1999), available at http://www.federalreserve.gov/board docs/speeches/1999/19990319.htm ("At year-end [1998], U.S. commercial banks, the leading players in global derivatives markets, reported outstanding derivatives contracts with a notional value of $\$ 33$ trillion, a measure that has been growing at a compound annual rate of around 20 percent since 1990.").

154. The ISDA took a leading role in the promotion and drafting of the safe harbor. See, e.g., Brief for the International Swaps and Derivatives Association, Inc. as Amicus Curiae supporting Appellants at 2-3, In re Nat'l Gas Distribs., L.L.C., 556 F.3d 247 (4th Cir. 2009) (No. 07-2105) 2008 WL 412344 ("ISDA was specifically thanked by Senator Dennis Deconcini for its role in the 1990 legislation that first created Bankruptcy Code safe harbors for swap agreements."). See generally supra note 152 and accompanying text.

155. Bradley A. Hansen \& Mary Eschelbach Hansen, The Role of Path Dependence in the Development of U.S. Bankruptcy Law, 1880-1883 7 (Am. Univ. Dep't of Econ. Working Paper Series, Working Paper No. 2005-14, 2005) [hereinafter Hansen \& Hansen Working Paper]. 
Ironically, the increase in the size of the derivatives industry was itself partly fostered by the safe harbor, which encouraged firms to deviate away from traditional financing into exotic derivatives to avoid application of bankruptcy law. ${ }^{156}$ And that, in turn, has made the financial system even more complex, further reinforcing the informational blindness. ${ }^{157}$

The safe harbor has by now become so embedded in the norms regarding bankruptcy treatment of derivatives that changes would be costly. ${ }^{158}$ This also parallels the observation that the choice of a certain legal path can encourage affected actors to invest resources in practices that conform to that path, thereby further locking it in:

[I]nstitutions and structures might have already developed to address needs and problems arising under these rules.... Various players-managers, owners, lawyers, accountants, and so forth-might have invested in human capital and modes of operation that fit the existing ... rules. Replacing these rules would require these players to make new investments and to adapt to the new rules, [thereby] reinforc[ing] [the] existing rules . . . ${ }^{159}$

\section{Reassessing the Derivatives Safe Harbor}

Path-dependent legislation is not necessarily bad. Nonetheless, if such legislation is not fully vetted, its significance and utility should not be taken for granted. In this Part, we review the existing scholarship that substantively engages the merits of the safe harbor. Although we have not made an independent analysis of the merits of the safe harbor, our review indicates that some scholars seriously question whether its benefits exceed its costs.

156. See Mark J. Roe, The Derivatives Market's Payment Priorities as Financial Crisis Accelerator, 63 STAN. L. REV. 539, 559 (2011) [hereinafter Derivatives Market's Payment] (discussing the relationship between derivatives and the Bankruptcy Code).

157. See supra notes 131-39 and accompanying text (discussing informational blindness).

158. See supra note 31 and accompanying text (observing that resources invested in an original road and its surroundings may well render the paving of a straight new road too costly).

159. Bebchuk \& Roe, supra note 39 , at 156. 


\section{A. Does Market Concentration Justify the Safe Harbor?}

The characteristics of the derivatives market have contributed to the belief that a collapse of a derivatives counterparty might precipitate a systemic meltdown. ${ }^{160}$ The trade in derivatives is concentrated among relatively few major firms. ${ }^{161}$ It therefore is feared that the collapse of a single firm, especially a highly connected one, might systemically disrupt the derivatives market, which could then impact the financial system more broadly:

Much OTC [over-the-counter] derivatives activity in the United States is concentrated among 15 major U.S. dealers that are extensively linked to one another, end-users, and the exchange-traded markets. This combination of global involvement, concentration, and linkages means that the sudden failure or abrupt withdrawal from trading of any of these large dealers could cause liquidity problems in the markets and could also pose risks to the others, including federally insured banks and the financial system as a whole..$^{162}$

160. See Waldman, supra note 19, at 1055 ("Following substantial market losses, there is the risk that the failure of one significant participant to make payments could result in ... a rapid, global transmission of defaults .... This risk is heightened by the fact that much of the derivatives business is concentrated in a small number of banks." (emphasis added)). See also DAVID SkeEl, The New Financial Deal: Understanding The DodD-Frank ACT AND ITS (UNINTENDED) CONSEQUENCES 135 (2011) ("The argument that serious counterparty risk was at stake was based on the concentration of the derivatives industry, with the major players-known before the crisis as the Fourteen Families - heavily connected with one another. If one fell, some have argued, the others could fall.").

161. See Financial Crisis Inquiry Comm'n, The Financial Crisis Report: Final REPORT OF THE NATIONAL COMMISSION ON THE CAUSES OF THE FinANCIAL AND ECONOMIC CRISIS IN THE UNITED STATES 50 (2011) ("Among U.S. bank holding companies, of the notional amount of OTC derivatives, millions of contracts, were traded by... many of the same firms that would find themselves in trouble during the financial crisis. The country's five largest investment banks were also among the world's largest OTC derivatives dealers.").

162. U.S. Gen. ACcounting Office, Financial Derivatives: Actions NeEded to Protect tHe Financial System 7 (1994). See also Edwards \& Morrison, supra note 20, at 98 (observing that "[f]ear that a counterparty insolvency could trigger a systemic meltdown in the 'over-the-counter' (OTC) derivatives market stems partly from the fact that this huge market is dominated by a few large international banks and securities firms"). Based on a 2009 Office of the Comptroller of the Currency study, Professor Roe reports that 
This systemic risk story, however, is far from proved. There is "little actual evidence to support" the story. ${ }^{163}$ On the other hand, based on a 2004 ISDA study, economists Bliss and Kaufman estimated that the net exposure of the major derivatives dealers to their five largest dealer counterparties (adjusting for collateral) averaged only $1.15 \%{ }^{164}$ If this estimate is correct-the estimate might be inaccurate in individual cases because its adjustment for collateral does not take into account dealers' increased exposure due to asset fire-sale runs, and the estimate is somewhat circular insofar as it is based on full netting which might be facilitated by the safe harbor ${ }^{165}$-it is highly unlikely that a collapse of one dealer could directly cause the failure of another major dealer. ${ }^{166}$

It is also ironic that the safe harbor itself may have exacerbated the movement toward market concentration of the derivatives industry, including by reducing derivatives traders' incentives to diversify and monitor their counterparties' profiles. ${ }^{167}$ For example, the safe harbor enables creditors to ignore counterparty risk because a creditor can foreclose on the collateral notwithstanding the counterparty's bankruptcy. ${ }^{168}$ This

"[t]he derivatives market is strongly centralized, with five firms accounting for nearly $90 \%$ of the industry's net credit exposure." Roe, Derivatives Market's Payment, supra note 156, at 561.

163. Lubben, Repeal, supra note 51, at 331. Professor Lubben observes that "there is little actual evidence to support even th[e] narrow claim" that "the special interrelations among financial firms, combined with some special volatility of derivatives, necessitates altering the Bankruptcy Code to prevent a systemic crisis." Id.

164. See Bliss \& Kaufman, supra note 77 , at 67 (discussing the actual net exposure).

165. See id. (discussing the effect of the safe harbor). The estimate is not, however, entirely circular: it does not necessarily assume unrestricted collateral enforcement, nor does it assume close-out of derivatives positions. See id. (discussing the "systemic risk argument").

166. See id. at 68 (discussing the risk among dealers); SkEEL, supra note 160 , at 135 (referring to the concentration argument in favor of the safe harbor). Skeel observes that "we know now that Lehman's bankruptcy filing did not lead to the failure of any of the bank's counterparties ... . Within a couple of weeks, the vast majority [of Lehman's derivatives trades] had been closed out, without any of the counterparties failing." Id.

167. See PWG REPORT, supra note 83 , at 8 (noting that "counterparties typically use collateral as a risk mitigation device").

168. See id. (discussing "collateral practices"). 
means that creditors "are not overly concerned with their debtor's financial stability, because they protect themselves with the debtor's collateral, rather than with their understanding of the firm itself." ${ }^{169}$ As a result, systemic risk actually may increase:

[I] $f$ the superpriorities had not been in place when Lehman built its capital structure and derivatives portfolio, Lehman's derivatives and repo counterparties' incentives to insist upon a more stable Lehman would have been greater. And Lehman itself would have been incentivized to keep to a safer capital structure to encourage its counterparties to keep dealing with it at low cost. 170

Lack of information regarding the financial condition and resiliency of derivatives counterparties can also make market participants more likely to overreact to new information regarding liquidity constraints in financial markets. ${ }^{171}$ Unable to distinguish "good" firms from "bad," market participants may overreact, posing a threat to the entire financial system. ${ }^{172}$ This adverse selection was seen in the financial crisis "when there was a run on the investments banks and money market funds after Lehman Brothers failed.... Like past runs, the runs on investment banks and money market funds occurred because there was uncertainty and lack of information about the health of these institutions...."173

The safe harbor's close-out netting provisions, which are exempted from the automatic stay, can also contribute to increased market concentration. Unrestricted close-out netting permits derivatives positions to be adjusted by executing an offsetting position with the same party without incurring

169. Roe, Derivatives Market's Payment, supra note 156, at 559.

170. Id. at 554 .

171. See Judge, supra note 56 , at 696 (discussing how the availability of information affects systemic risks).

172. See id. (discussing "common mode failure" which "arises when the failure of one financial institution sends signals to the marketplace about the financial well-being of other institutions with similar exposures. If market participants were perfectly informed, of course, a failure would not convey any new information").

173. Viral V. Acharya et. al, Market Failures and Regulatory Failures: Lessons from Past and Present Financial Crises, in MASAHIRo KaWAI AND EswaR Prasad, Financlal Market Regulation And Reforms In EMERging Markets 64 (2011). 
additional costs (in terms of cash flow, collateral, credit risk management, or even being required to engage the market for an alternative offsetting position from a weak bargaining stand). ${ }^{174}$ That in turn allows market participants to concentrate their positions with relatively few dealers. ${ }^{175}$ Without unrestricted close-out netting, "the concentrations we see in the dealer market which give rise to systemic concerns simply would likely not exist [because] [t]he capital available to support gross credit risk exposures would far exceed the capital currently needed to support net exposures." 176

\section{B. Is the Safe Harbor Focused on the Right Parties?}

Professors Edwards and Morrison observe that the fear of derivatives-induced systemic risk is warranted only in the case of an insolvency of a major financial market participant holding a massive derivatives portfolio. ${ }^{177}$ The safe harbor's exemptions, however, operate independently of the size of the counterparty or its portfolio. ${ }^{178}$ Furthermore, they apply not only to financial firms but to any firm that holds a derivative. ${ }^{179}$ Thus a bank that makes a secured loan cannot enforce its collateral against a

174. See Bliss \& Kaufman, supra note 77 , at 62 (discussing how position netting permits troubled companies to remain active in the market).

175. See id. at 61 (observing that this creates "incentives to deal with one counterparty rather than many").

176. Id. at 67. Although ISDA has expressed concerns regarding the increase in exposure that could result from limiting the safe harbor, such an increase would likely be temporary, diminishing as market participants rearrange their portfolios to adapt to the changed risk. See Mengle, supra note 2 , at 6 (discussing the dangers of reducing the safe harbor provisions).

177. See Edwards \& Morrison, supra note 20, at 98 (discussing the possible market effects of the failure of a "major financial market participant").

178. See id. (noting that the Code provides protections to large market players).

179. See Lubben, Repeal, supra note 51, at 328 (discussing the role of safe harbors in reducing risk). Lubben observes, for example, that

the argument for the safe harbors is quite simple: the safe harbors reduce systemic risk by giving large financial institutions special treatment. This argument only holds, if at all, with regard to derivative transactions among financial institutions, and thus supports only a much narrower version of the existing safe harbors.

Id. at 331 . 
bankrupt borrower, whereas an ordinary business firm can enforce its collateral against a bankrupt derivatives counterparty. ${ }^{180}$ The safe harbor exemptions may go well beyond the underlying goal of reducing systemic risk. ${ }^{181}$

It is unclear if that breadth is needed. Some argue, for example, that although the systemic risk argument cannot justify a blanket protection to all market participants, it is impractical to base laws on the size of the affected party. ${ }^{182}$ Others acknowledge that while a "more fine-grained approach that applied the automatic stay to [only] some derivatives ... would complicate the treatment of derivatives in bankruptcy,"183 a "more nuanced approach is preferable to adopting a blanket rule that invites strategic termination by non-debtors." 184

\section{Possible Unintended Consequences}

In its current form, the safe harbor may well have unintended harmful consequences. In this subpart, we will discuss the possibility that close-out netting can cause the equivalent of a "bank run," and also the likelihood that the safe

180. See supra notes $162-66$ and accompanying text (discussing the applicability of the safe harbor provisions to large market participants).

181. See Hance, supra note 59, at 759-61 (debunking the systemic risk argument); Lubben, Derivatives and Bankruptcy, supra note 56, at 75 (discussing the end result of "wealth transfer" between market participants); Vasser, supra note 10, at 1542 (questioning the validity of the systemic risk argument).

182. See Bliss \& Kaufman, supra note 77 , at 68 (discussing the different effects between large and small business failures).

183. Frank Partnoy \& David A. Skeel, Jr., The Promise and Perils of Credit Derivatives, 75 U. CiN. L. REv. 1019, 1050 (2007).

184. Id. The safe harbor might itself facilitate systemic risk. For example, the Financial Stability Oversight Council identified the absence of a bankruptcy mechanism to facilitate the orderly liquidation of a defaulted dealer's collateral as one of "ongoing vulnerabilities" in the repo market. See FINANCIAL STABILITY OVERSIGHT COUNCIL: 2012 ANNUAL REPORT 133, available at http://www. treasury.gov/initiatives/fsoc/Pages/annual-report.aspx (discussing the "sources of vulnerability ... of great concern to the Council"). This vulnerability created a systemic risk of market collapse caused by the "fire sale" of a defaulting dealer's collateral. Id. As the FSOC observed, the exclusion of derivatives from bankruptcy's automatic stay left financial markets in a void with no protection against abrupt liquidity changes. See id. (discussing the "absence of a mechanism to facilitate orderly liquidation of a defaulted dealer's collateral"). 
harbor's breadth enables virtually any financial contract, including an ordinary secured loan, to be documented as a derivatives transaction, thereby exempting the contract from the automatic stay and other critical bankruptcy provisions. ${ }^{185}$

Close-out Netting Can Trigger the Equivalent of Bank Runs. Recall that the PWG Report's central recommendation was that close-out netting should be exempted from the Bankruptcy Code's automatic stay and other restrictions. ${ }^{186}$ The Report's rationale was that close-out netting would help to mitigate counterparty losses and thus reduce the likelihood of instability in financial markets. ${ }^{187}$ Professors Edwards and Morrison argue to the

185. See generally infra notes 186-215 and accompanying text. We already have mentioned other potential unintended consequences of the safe harbor: that stronger netting might backfire by motivating increased counterparty concentration, thereby increasing systemic risk. See generally supra notes 12324, 168-70 and accompanying text. Also, master netting could deprive a debtor of much-needed cash collateral, which in some instances may lead to conversion and liquidation to the detriment of other creditors. See generally supra notes 117-18 and accompanying text. The safe harbor might have an additional unintended consequence. The PWG Report's favoring of netting provisions, being focused on damage to the derivatives market as a whole, overlooks the danger of systemic risk as a result of a specific counterparty collapse. For example, if netting provisions were subject to the automatic stay, LTCM would have had to engage a larger number of counterparties in order to reach the same gross positions. This, in turn, would have meant that each counterparty was less exposed to an LTCM default because the individual gross positions of each counterparty with LTCM would have been smaller. Thus, if LTCM had gone into bankruptcy under a no-safe-harbor regime, the market as a whole would have suffered the same gross damage, but its sustainability would have been higher. Market diversity reduces the possibility of any given firm sustaining larger losses than its loss absorption capability. David Skeel notes that due to safe harbor privileges,

rather than spreading their derivatives business among a multitude of counterparties, [derivatives participants] can feel free to load up on derivatives with [a single counterparty] . . . By lowering the risks of having a large exposure to any given counterparty, the special derivatives rules have thus diminished the incentives for a bank to spread its derivatives business around .... If derivatives and other financial instruments were subject to the same core principles as other contracts[,] ... derivatives creditors would pay much closer attention to a debtor's financial condition, and they would be much more careful to limit their exposure to any particular institution ...."

SKEEL, supra note 160, at 161-62; see also Roe, Derivatives Market's Payment, supra note 156, at 561-62 (discussing mechanisms in the derivatives market).

186. See generally supra notes 93-96 and accompanying text.

187. See generally supra notes $93-96$ and accompanying text. 
contrary, however, that unrestricted close-out netting can trigger the equivalent of a bank run. ${ }^{188}$

Using LTCM as an example, they contend that unrestricted close-out netting would have motivated LTCM's creditors to rush to net and close out their positions. ${ }^{189}$ That, in turn, could have caused or exacerbated "liquidity shortages, resulting in systemic illiquidity with the potential to cause widespread contagion." 190 They also argue that such a rush "could have resulted in the immediate and widespread liquidation of assets at fire sale prices." ${ }^{191}$ Absent unrestricted close-out netting, however, Edwards and Morrison believe that

LTCM's major creditors almost certainly would have opted to facilitate a bankruptcy supervised creditor "work-out" by putting in more capital and reorganizing the ownership structure of LTCM, just as they did under the Federal Reserve arranged work-out. Indeed, as subsequent events showed, it was clearly in the collective interest of LTCM's counterparties and creditors to avoid a "run" on LTCM and the accompanying firesale of its assets. Thus, in the absence of the Bankruptcy Code's special treatment of derivatives, Fed intervention may have been unnecessary. ${ }^{192}$

188. See Edwards \& Morrision, supra note 20, at 101 (discussing the LTCM example and the possibility of "widespread liquidation of assets at fire sale prices").

189. See id. at 101 (discussing the possible effects of close-out netting in the LTCM example).

190. Id.

191. Id. Other scholars suggest that these systemic illiquidity and liquidation concerns could be muted, however, by steps such as allowing regulators a limited period of time (e.g., 24 hours) to transfer derivatives of a failed counterparty to third parties. See Viral V. ACHARYa, Thomas F. CoOley, MatTheW Richardson \& Ingo Walter, Regulating Wall StreEt: The DodDFrank ACt AND the New ARchitecture of Global Finance 27-28 (2011) (discussing remedies for system illiquidity). But cf. Mengle, supra note 2, at 6 (cautioning that delays longer than twenty-four hours "might unnecessarily expose market participants to market risks"). Some of these suggestions were incorporated into the Dodd-Frank Act's Orderly Liquidation Authority, but Stephen Adams has argued that the passage of the OLA may increase the need to address the bankruptcy safe harbor both by undermining its primary justification and by the threat of interference with the OLA's effectiveness. See Adams, supra note 57, at 24-27 (discussing the role of the safe harbor provisions in relation to the OLA).

192. Edwards \& Morrison, supra note 20, at 103. 
We do not purport in this discussion to independently critique the merits of unrestricted close-out netting. Our point is simply that it has been the subject of serious criticism by respected scholars. ${ }^{193}$ ISDA's Head of Research has responded to such criticism but only in generalities, including observing the international legal harmonization towards allowing unrestricted close-out netting. ${ }^{194}$ The fact that something is occurring does not necessarily mean, however, that it should be occurring ${ }^{195}$ especially when lobbying is a cause of what is occurring. ${ }^{196}$

The Safe Harbor's Breadth Enables Ordinary Financial Contracts to be Documented as Derivatives Transactions. Because derivatives transactions are exempted from bankruptcy law, another unintended consequence is that parties are tempted to try to document ordinary financial transactions as derivatives

193. See Mengle, supra note 2, at 5 (observing that "a handful of academics and bankruptcy lawyers in the United States [have] suggest[ed] that the [closeout netting] safe harbor[ be abolished altogether"). Mengle notes that the commentators cite

a variety of justifications: one commentator argues that the ability to terminate can lead to systemic crisis; others suggest that close-out netting and other risk mitigation mechanisms reduce incentives to monitor credit quality; and still others argue that close-out netting works at cross-purposes to the objectives of bankruptcy by redistributing risk from derivatives participants to other parties. Id.

194. See id. at 5 (maintaining that "inability to terminate or net contracts with an insolvent firm would leave surviving firms vulnerable to losses caused by sudden market changes"). The argument takes into account ex post but not ex ante implications, disregarding how increased exposure would motivate derivatives counterparties to diversify and monitor. See generally supra notes 175-76 and accompanying text. Mengle observes that

more generally, changing the treatment of derivatives and other financial contracts would represent a major departure by the United States from the trend toward cross-border convergence of the treatment of derivatives in insolvency and from the widespread acknowledgement by policy makers of the contribution of netting to financial stability.

Mengle, supra note 2, at 5. Cf. Bergman et al., supra note 2, at 2 (observing that the safe harbor types of exemptions "represent[ one of the few successes in international legal harmonization").

195. G.E. MooRe, PRINCIPIA EthiCA 10-14 (1971).

196. See Enrico Perotti, Systemic Liquidity Risk and Bankruptcy Exceptions, DSF POL'Y PAPER SERIES, No. 8, at 4-5 (Oct. 2010) (observing that the safe harbor provisions were "heavily lobbied by the financial industry"). 
transactions in order to benefit from the exemption. ${ }^{197}$ During the deliberations preceding the 1990 amendment to the safe harbor, Professor Picker even warned Congress that " $t]$ he expansion of these provisions would take us farther down the path of allowing sophisticated parties to opt out of bankruptcy."198

The safe harbor is now so broad that, it appears, virtually any ordinary financial transaction can be documented to fall within it. ${ }^{199}$ The safe harbor uses broad definitions of derivatives, no longer requiring that they be traded on financial markets or be physically settled. ${ }^{200}$ Although some courts have tried to resist overly broad categorization of ordinary financial contracts as derivatives, they have been overruled on appeal due to the breadth of the safe harbor. ${ }^{201}$

In In re National Gas Distributors, L.L.C. ${ }^{202}$ for example, the lower court found that ordinary agreements to purchase commodities should not be treated as derivatives and therefore should not be exempt from bankruptcy law. ${ }^{203}$ The court feared a slippery slope: that exempting ordinary contracts as derivatives would disrupt

the overall scheme of the Bankruptcy Code. If this agreement is a [derivative] agreement, then many of the most important aspects of the Code, including priorities of distributions to creditors and the automatic stay, will be eviscerated in even the smallest case of a farmer who contracts to sell his hogs at the end of the month for a set price. No public purpose would be served, and the result would be wholly at odds with the established aims and order of bankruptcy proceedings. ${ }^{204}$

197. See generally infra note 209 and accompanying text.

198. Bankruptcy Reform Act of 1999 (Part III), Hearing on H.R. 833 Before the Subcomm. on Commercial and Administrative Law of the House Comm. on the Judiciary, 106th Cong. 179 (statement of Randal Picker, on behalf of the National Bankruptcy Conference).

199. See generally infra note 209 and accompanying text.

200. See generally supra notes 110-27 and accompanying text.

201. See generally infra notes 202-15 and accompanying text.

202. 369 B.R. 884 (Bankr. E.D.N.C. 2007).

203. See id. at 899-900 (concluding that the agreements were not "swap agreements").

204. Id. at 900 . 
On appeal, however, the court's decision was reversed, given the breadth of the safe harbor language. ${ }^{205}$

Similarly, in In re MBS Management Services, ${ }^{206}$ a lower court held that an ordinary electricity supply contracts was a derivatives contract and thus exempt from bankruptcy law: "[a]dmittedly, even supply contracts have hedging or risk management attributes. By setting the price for electrical power, end users protect themselves against large fluctuations in price and stabilize their cost of power."207 The lower court's reasoning, which cited with favor the proposition that there is "no reason ... to distinguish between [derivatives] contracts, and 'ordinary purchase and sale' forward contracts, when the statutory language makes no such distinction," was approved by the Fifth Circuit Court of Appeals. ${ }^{208}$

Under the current safe harbor language, virtually any financial contract, including an ordinary secured loan, might be able to be documented as a derivatives transaction, thereby exempting it from the automatic stay and other critical bankruptcy provisions. ${ }^{209}$ Some textbooks are openly encouraging parties to design financing contracts as derivatives transactions, in order to circumvent the Bankruptcy Code's restrictions. ${ }^{210}$

205. See supra notes 142-46 and accompanying text (discussing the National Gas decision in the Fourth Circuit).

206. 432 B.R. 570 (Bankr. E.D. La. 2010).

207. Id. at 576 .

208. See In re MBS Mgmt. Servs., Inc., 690 F.3d 352, 357-58 (5th Cir. 2012) (affirming the lower court's reasoning and holding).

209. See Kenneth N. Klee, Professor of Law, UCLA School of Law, and Senior Partner, Klee, Tuchin, Bogdanoff, \& Stern LLP, Statement at the International Insolvency Institute, Seventh Annual Conference: Understanding Derivatives: Dissecting Complex Financial Instruments (June 12, 2007) (discussing the broad nature of the current safe harbor provision). Others have made similar observations. See, e.g., Campbell, supra note 89, at 712 (stating that a "cynic might argue that the financial safe harbor [is] indeed a 'bankruptcy opt-out clause' for a certain class of capitalists because their money is more important than everyone else's"); Morrison \& Riegel, supra note 10, at $642,647,660,663$ (discussing various ways financial market participants can use the Code provisions to their advantage); Christopher J. Redd, Treatment of Securities and Derivatives Transactions in Bankruptcy, Part I, 24-6 AM. BANKR. INST. J 36, 37 (2005) ("The [Code] provisions generally operate to exempt a large number of routine financial market payments and transfers from the Code's automatic stay and avoidance provisions.").

210. See Edwards \& Morrison, supra note 20, at 121 (discussing other 
Indeed, one of the authors was recently told, in confidence, by a prominent financing lawyer that it could be malpractice for lender's counsel to draft a secured loan as an ordinary loan and security agreement, because drafting it as a derivatives contract would allow the secured lender to foreclose notwithstanding the automatic stay. ${ }^{211}$ Professors Frank Partnoy and David A. Skeel, Jr. have observed, in this context, that the costs of completely excluding derivatives from the protections that bankruptcy law gives debtors are likely to rise, as firms increasingly turn to derivatives as a substitute for traditional financial instruments. ${ }^{212}$

It thus is clear that the safe harbor is too broad, but if a safe harbor is needed-a question as to which we are agnostic-it may be difficult to design a more limited set of exemptions. One problem is that numerous bankruptcy judges, with varied backgrounds, preside over cases involving derivatives, so "predicting the treatment of complicated financial contracts upon a future bankruptcy filing would be quite difficult." ${ }^{213}$ The resulting uncertainty "might have detrimental (i.e., inefficient) effects on the larger derivatives markets, which has importance well beyond the world of bankruptcy."214 The experience of judges applying the safe harbor in its earlier (and narrower) years showed the pitfalls of trying to differentiate exempted and nonexempted transactions. ${ }^{215}$

\section{Conclusions}

In the United States, bankruptcy law grants special rights and immunities to creditors in derivatives transactions, including virtually unlimited enforcement rights. ${ }^{216}$ This Article has argued

commentators advice on how to "use derivatives contracts to reduce the costs of bankruptcy").

211. See 11 U.S.C. $\S 362$ (a) (establishing the automatic stay provisions).

212. See Partnoy \& Skeel, supra note 183, at 1050 (arguing for a "more nuanced approach" for derivatives, rather than a "blanket exception").

213. Lubben, Derivatives and Bankruptcy, supra note 56, at 75.

214. Id.

215. See Morrison \& Riegel, supra note 10, at 645-47 (discussing the difficulty in defining and applying certain provisions in the previous code).

216. See generally supra Part II. 
that these rights and immunities are largely path dependent, resulting from a sequence of incremental industry-lobbied legislative steps, without systematic and rigorous vetting of the consequences. ${ }^{217}$

Because the resulting derivatives "safe harbor" has not been fully vetted, its significance and utility should not be taken for granted. Regulators, legislators, and other policymakerswhether in the United States or abroad-should not automatically assume that the safe harbor necessarily reflects the most appropriate treatment of derivatives transactions under bankruptcy and insolvency law, or the treatment most likely to minimize systemic risk. ${ }^{218}$

We do not argue that the safe harbor is necessarily bad. Because we have not made an independent investigation of the safe harbor's merits, we are agnostic. A path-dependent result is neither intrinsically good nor bad.219 For example, the pathdependent U.S. corporate management model, which favors strong managers over strong owners, is not necessarily better or worse than the converse; it is just that there has been neither a fully informed discussion in the United States regarding the benefits of one model over the other nor an economic "battle" between the two models. ${ }^{220}$ Stakeholders, legislators, and policymakers took for granted and adapted to the model that evolved, without questioning it. 221

Sometimes, however, path-dependent outcomes can have adverse consequences. ${ }^{222}$ Our review indicates that some scholars

217. See generally supra Part V.

218. See generally supra Part V.B.

219. See Roe, Chaos, supra note 27, at 647-51 (describing three forms of path dependence, with only two leading to inefficient outcomes).

220. See id. at 646 (discussing the lack of comparative data or information).

221. See id. (noting the lack of comprehensive research of multiple perspectives on the issue).

222. See id. at 660 (identifying a regulation that bars bondholders from voting to approve recapitalization schemes if the scheme includes provisions that change the maturity date or the principal amount of the bonds). According to Roe, this regulation is rooted in a 1928 New York Appellate Division decision that interpreted the then New York Negotiable Instruments Law. See id. at 664 (noting the condition came from the court, not "bond market efficiency, bond market fairness, or securities laws"). The decision, which held that a bond allowing a vote to change the maturity date or principal is nonnegotiable, was turned into a regulation during the Great Depression. See id. at 661 (discussing 
believe that the derivatives safe harbor can be harmful, not only potentially increasing systemic risk but also possibly undermining the application of bankruptcy law to financial contracts generally. ${ }^{223}$ We therefore suggest that a more fully informed discussion of the merits of the derivatives safe harborunder U.S. bankruptcy law, and under foreign insolvency laws to the extent such laws incorporate similar derivatives exemptions-may well be timely.

Finally, our analysis suggests that heightened informational burdens due to complexity and uncertainty can increase the influence of interest-group politics. ${ }^{224}$ That, in turn, can make legislation more vulnerable to legal path dependency, especially when-as in the case of the derivatives safe harbor-no powerful interest groups present opposing views. ${ }^{225}$ In the face of increasing financial complexity, further research into the causes and consequences of legal path dependency may be warranted.

the effects of the decision). Changes in the structure of the bond market rendered the regulation superfluous and cumbersome, but despite having no economic rationale, the regulation still exists. See id. at 661-62 (discussing the path dependency of the regulation). To overcome it, the bond market and the surrounding legal infrastructure had to adapt to the existing legal frame. See id. at 662 (noting the "jerry-rigged adaptations [that] allowed it to survive"). The 1978 Bankruptcy Code allowed such votes as part of a "pre-packaged bankruptcy," and market pressure led authorities to permit numerous prohibited recapitalization schemes under an "emergency" financial necessity label. See id. (discussing how the law's application created a need for adaptations). Nevertheless, the specific provision that bars certain recapitalization schemes was not revoked. See id. (discussing how the law adapted but was not repealed because of path dependency).

223. See generally supra Part IV.

224. See supra notes 134-37 (observing that the informational blindness was almost certainly exacerbated by the complexity of derivatives and uncertainty about systemic risk, and in the face of complexity and uncertainty, people tend to see what they expect to see with the expectation in this case being driven by lobbyist pressure).

225. See generally supra notes 131-56 and accompanying text. Legal pathdependency is premised on two change-impeding features: information burdens and interest-group politics. Path dependency information burdens have two features: the difficulty to think on alternative paths and customary perception that impedes change (such as the human tendency to rely on simplifications in the face of complexity). As we demonstrated, both these features are inherent in complex systems. 